\title{
Effect of monoclonal and assorted seedling rootstocks on long term growth and yield of Hevea clones
}

\author{
By T. Gireesh*), Y. Annamma Varghese, K. E. Woeste ${ }^{1), 2)}$, V. C. Mercykutty and J. G. Marattukalam \\ Rubber Research Institute of India, Kottayam 686009, Kerala State, India
}

(Received $4^{\text {th }}$ July 2011)

\begin{abstract}
Seven Hevea brasiliensis clones were evaluated on two types of rootstocks, assorted seedling rootstocks (AR) and monoclonal rootstock (MR) over 19 years. Influence of rootstock on scion growth and rubber yield was assessed based on juvenile height, circumference of the main trunk $(\mathrm{cm})$, number of branches, branching height and cumulative dry rubber yield (g per tree per tapping, conventionally abbreviated $\left.\mathrm{gt}^{-1} \mathrm{t}^{-1}\right)$. Highest cumulative yield (g per tree per tapping) over the 12 years for which the trees were tapped was obtained from clone RRII 105 (MR: $1076 \mathrm{~g}$ per tree per tapping and AR: $497 \mathrm{~g}$ per tree per tapping), followed by RRII 203 (MR: 661; AR: 538), RRII 208 (MR: 477; AR: 486), RRII 118 (MR: 497; AR: 452). Gl 1 yielded the least, $219 \mathrm{~g}$ per tree per tapping (MR) and $378 \mathrm{~g}$ per tree per tapping (AR); GT1 produced $335 \mathrm{~g}$ per tree per tapping $(\mathrm{MR})$ and $375 \mathrm{~g}$ per tree per tapping (AR). RRII 118 had the greatest circumference at age $19(91.4 \mathrm{~cm}$ on MR) 88.8 on AR, followed by RRII 105 (MR: $87.4 \mathrm{~cm}$ AR: $89.2 \mathrm{~cm}$ ) and GT 1 (MR: $88.5 \mathrm{~cm}$; AR: $84.4 \mathrm{~cm})$. Effect of scion clone was significant $(p<0.01)$ only for trunk circumference at opening, but not for cumulative rubber yield at age 11 (4 years after opening) or cumulative rubber yield at age 19 (12 years after opening). Most importantly, rootstock and clone $\mathrm{x}$ rootstock interaction did not significantly affect rubber yield or tree circumference at any evaluation time. There was no evidence to suggest that growth and yield of clones was influenced significantly by rootstock type.
\end{abstract}

Key words: Natural rubber, rootstock-scion, Hevea brasiliensis.

\section{Introduction}

Hevea brasiliensis (Willd. ex Adr. de Juss.) Muell.-Arg. the Para rubber tree, is one of only a few species that produces high quality natural rubber, an important commercial raw material with multiple applications. High yielding Hevea clones are commonly propagated through grafting in order to capture dramatic gains in

\footnotetext{
1) USDA Forest Service Hardwood Tree Improvement and Regeneration Center, Department of Forestry and Natural Resources, Purdue University, 715 W. State St., West Lafayette, IN 47907-2061, USA.

2) Mention of a trademark, proprietary product, or vendor does not constitute a guarantee or warranty of the product by the U.S. Dept. of Agriculture and does not imply its approval to the exclusion of other products or vendors that also may be suitable.

*) Corresponding author: T. GIREESH. Phone: 91-481-2353311 to 2353320, Fax: 91-481-2353327. E-Mail: gireesh@rubberboard. org.in
}

rubber yield made through systematic breeding and selection (LICY et al., 2003; PRIYADARSHAN and CLEMETDEMANG, 2004) and to help growers increase the size and uniformity of their trees. WHITBY (1919); SHARP (1940) and SENANAYAKE et al. (1975) reported that the coefficient of variation (CV) among seedling populations was very high. Intraclonal variability has also been reported (CHANDRASEKHAR et al., 1997). SENANAYAKE (1975) reported 27 percent $\mathrm{CV}$ among ramets of the clone RRIC 88; CV was 30 percent among ramets of clone RRIM 623 (ALIKA, 1980). Physiological and biochemical evidence (SOBHANA et al., 2001; YUAN et al., 2011 ) and studies on intraclonal variation of 13 clones and the association of juvenile yield and stem diameter (PREMAKUMARI et al., 2002) found that variability was very low for stem diameter, but higher for test tap yield up to year three.

Vegetative multiplication through bud grafting involves rootstock and scion. Rootstocks are mainly raised from healthy seeds and the scion belongs to an elite genotype. Since the adoption of budding as a method of propagation in Hevea, there have been host of studies investigating stock-scion interaction; similar studies have been published in other important vegetatively propagated tree crops like apple (ZHU et al., 1999; JENSEN et al., 2003), apricot (SALAZAR et al., 1991), citrus (CASTle and Youtsey, 1998), cocoa (Yin, 2004), peach (TOMBESI et al., 2010), teak (SHARMA and UNIYAL, 2003). In Hevea, latex yield depends largely on the genotype of the scion (BUTTERY, 1961), but there are arguments supporting the influence of rootstock for example, KRISHNAKUMAR et al. (1992) reported variation in the expression of polymorphic isoenzymes caused the rootstockscion interaction.

Production of clonal rootstocks is still not commercially feasible. Estimation of general compatibility (rootstocks and scion) and specific compatibility (for all combinations of six rootstocks and scions) for rubber yield, showed a strong rootstock effect on yield (CARDINAL et al., 2007). Long term data related to the effect of rootstock on scion performance in the traditional rubber growing belt of southern India is meager, and most of the previous studies were confined to parameters other than long term growth and yield. The objective of the present work was to demonstrate the influence of rootstock-scion combination on juvenile characteristics, growth and yield of seven popular Hevea clones grown on monoclonal rootstock (MR) and randomly assorted rootstocks (AR) over a period of nineteen years. 


\section{Materials and Methods}

\section{Location and Plant materials}

The study was performed at the Central Experiment Station of the Rubber Research Institute of India at Chethackal, Kerala State, South India (Latitude $9^{\circ} 22^{\prime} \mathrm{N}$, Longitude $76^{\circ} 5^{\prime} \mathrm{E}$; Altitude $100 \mathrm{~m}$ ). The planting materials consisted of seven clones developed for high rubber yield and of different genetic background (Table 1). These seven clones were budded onto monoclonal rootstocks (MR) from self pollinated seeds selected from clonal plantations as described earlier (NG et al., 1981). The same scions were budded onto rootstock (AR) raised from seeds of unknown origin. Details of different rootstock-scion combinations are shown in the Table 2. The clones were budded onto corresponding rootstocks in the nursery. After successful bud grafting, stumps were planted in polythene bags ( $55 \mathrm{~cm} \times 25 \mathrm{~cm}$ when laid flat) filled with about $10 \mathrm{~kg}$ soil and raised in a nursery.

\section{Field planting and crop management}

Six month-old, two-whorl, brown-budded plants were planted in the field site in July 1984 in a randomizedcomplete-block-split-plot design with two blocks. Plot size was fixed to 25 trees at a spacing of $4.9 \mathrm{~m} \mathrm{x} 4.9 \mathrm{~m}$. The field had slightly undulating topography. Crop man- agement practices such as weeding, sun-scorch prevention, mulching and manuring were performed appropriately throughout the experiment as detailed in the PUNNOOSE et al. (2000).

\section{Assessment of growth and yield}

Parameters observed from the field grown plants in the first year after planting were (a) total height of the plant and (b) circumference of the main trunk (TC) measured at a height of $150 \mathrm{~cm}$ from the bud union. In the third year of planting, number of branches (c) above 2.5 $\mathrm{m}$ and height up to the lowest branch (d) were recorded. TC measurements were continued every year in the month of January. All trees were opened for tapping in the seventh year after planting. The tapping system followed was $\mathrm{S} / 2 \mathrm{~d} 36 \mathrm{~d} / 7$ (according to the conventions used in the rubber industry, $\mathrm{S} / 2$ indicates half spiral tapping, $\mathrm{d} / 3$ indicates tapping every third day, and $6 \mathrm{~d} / 7$ indicates available tapping days per week, i.e. 100 tappings per year). Dry rubber yield was measured from each experimental tree in grams per tree per tapping $\left(\mathrm{gt}^{-1} \mathrm{t}^{-1}\right)$ by coagulating the latex in collection cups once in a month (30-day interval). Mean dry rubber yield was recorded from 12 samples and expressed as $\mathrm{gt}^{-1} \mathrm{t}^{-1}$. Cumulative mean yield $\left(\mathrm{gt}^{-1} \mathrm{t}^{-1}\right)$ was computed at age 11 and 19.

Table 1. - Details of Hevea scion clones and their origin.

\begin{tabular}{|c|c|c|c|}
\hline Clonciscion & $\begin{array}{l}\text { Country of } \\
\text { origin }\end{array}$ & Parentage & Gencral fieatures \\
\hline RRII 105 & India & Tjje 1 x (jll & $\begin{array}{l}\text { A high yiclding clone identified in India, most popular varicty } \\
\text { occupying } 80 \text { percent of rubber cultivating areas in the traditional } \\
\text { zone; trunk tall. branches with strong unions: canopy dense but } \\
\text { restricted to the top, tolerant to abnomal leaf fall discase (NAIR } \\
\text { and GEORGF, 1969; ANN } A \text { MMA et al., 1990). }\end{array}$ \\
\hline RRII 118 & India & Mil $3 / 2 \times$ Hil 28 & $\begin{array}{l}\text { An Indian clone with vigorous growth; trunk tall and stout; } \\
\text { prominent hoavy branches; canopy dense, balaneed crown. Yicld } \\
\text { is average (NAIR and GEORGE, 1969; ANNAMMA ct al., 1990). }\end{array}$ \\
\hline RRII 203 & $\operatorname{lndja}$ & PB $86 \times \mathrm{Mil} 3 / 2$ & $\begin{array}{l}\text { A clone developed in India, with moderate rubber yield and high } \\
\text { timber yield (SARASWATIIAMMA at al., 1990). }\end{array}$ \\
\hline RRII 208 & India & Mil $3 / 2 \times \wedge V R O S 255$ & $\begin{array}{l}\text { Clome of Indian origin with above average yicld; and vigorous } \\
\text { growth characters (SARASWAIHIAMMA ct al., 1990). }\end{array}$ \\
\hline $\mathrm{GTl}$ & Indonesia & Primary clone & $\begin{array}{l}\text { A primary clone developed in Indonesia, extensively planted in } \\
\text { almost all rubber growing countries. Trunk upright, main } \\
\text { branches long. Moderate yiclder with rising yicld trend (RRIM, } \\
1970 \text { b). }\end{array}$ \\
\hline G1 1 & Valaysia & Primary clone & $\begin{array}{l}\text { A moderate yielding Malaysian primary clone, tolerant to } \\
\text { abnormal leaf fall discase, comparatively less vigorous in growth } \\
\text { (VAIR et al., 1975). }\end{array}$ \\
\hline RRIM 600 & Malaysia & Tjir $1 \times$ PB 86 & $\begin{array}{l}\text { A clone of Valaysian origin exlensively grown in almost all } \\
\text { rubber growing countries. J'runk is straight, moderate to fairly } \\
\text { heavy branches; with broom shaped crown. Susceptible to } \\
\text { abnormal lear fall discase (RRIM, I970a). }\end{array}$ \\
\hline
\end{tabular}


Table 2. - Stock-scion combinations and long term rubber yield.

\begin{tabular}{|c|c|c|c|c|c|c|}
\hline \multirow[b]{3}{*}{ Clones } & \multicolumn{2}{|c|}{ Rootstock type } & \multicolumn{4}{|c|}{$\begin{array}{l}\text { Cumulative rubber yield } \\
\text { (g per tree per lapping, } \mathrm{gl}^{-1} \mathrm{l}^{-1} \text { ) }\end{array}$} \\
\hline & \multirow{2}{*}{$\begin{array}{c}\text { Monoclonal' } \\
\text { (MR) }\end{array}$} & \multirow{2}{*}{$\begin{array}{l}\text { Assorted } \\
\text { (AR) }\end{array}$} & \multicolumn{2}{|c|}{11 -ycar-old trees } & \multicolumn{2}{|c|}{ 19-year-old trees" } \\
\hline & & & MR & $\mathrm{AR}$ & $\mathrm{MR}$ & $\mathrm{AR}$ \\
\hline RRII 105 & RRII 105 & Unknown & 252 & 140 & 1076 & 497 \\
\hline RRII 118 & RRII 118 & Unknown & 111 & 63 & 497 & 452 \\
\hline RRII 203 & RRII 203 & Unknown & 154 & 142 & 661 & 538 \\
\hline RRI] 208 & RRII 208 & Unknown & 124 & 123 & 477 & 486 \\
\hline GT 1 & GT 1 & Unknown & 75 & 78 & 335 & 375 \\
\hline Gl 1 & Gl I & Unknown & 57 & 122 & 219 & 378 \\
\hline RRIM 600 & RRIM 600 & Unknown & 230 & 102 & 643 & 196 \\
\hline
\end{tabular}

\footnotetext{
${ }^{z}$ Rootstock seedlings grown from monoclonal seeds.

y Rootstock seedlings from randomly collected seeds with unknown polyclonal origin.

${ }^{x}$ Cumulative yield at age 11 , first 4 years after opening, S.E. $=63.6$.

${ }^{v}$ MR versus AR comparison NS at $P=0.05$.

${ }^{\mathrm{w}}$ Cumulative yield at age 19, first twelve years after opening, S.E. $=236$.
}

\section{Statistical analysis}

The experiment was a simple two-factor randomized complete block design with two replications. There were seven clones on two rootstock types. The linear model was:

$$
\mathrm{y}_{\mathrm{ijk}}=\mu+\alpha_{\mathrm{i}}+\beta_{\mathrm{j}}+(\alpha \beta)_{\mathrm{ij}}+\varepsilon_{\mathrm{ijk}}
$$

where the $\mathrm{ijk}^{\text {th }}$ observation was the sum of the overall mean $(\mu)$ plus the effect of $i^{\text {th }}$ clone $\left(\alpha_{i}\right)$ in the $j^{\text {th }}$ replication $\left(\beta_{\mathrm{j}}\right)$ and the effect of clone $\mathrm{x}$ rep interaction $(\alpha \beta)_{\mathrm{ij}}$ and the error $\varepsilon$ of replication $\mathrm{k}$ associated with factor level ij. Rootstock, scion and rootstock-scion interaction effects on each variable were determined using analysis of variance, all comparisons were based on plot means, with comparisons adjusted using the Tukey-Kramer Method as implemented in SAS software, v. 9.1 (Carey, NC). Observations from the trees with wind damage or disease were eliminated from the analysis.

\section{Results}

Commercial exploitation by tapping begins only after a tree attains $50 \mathrm{~cm}$ TC, a trait commonly referred to as earliness. Earliness is one of the most important breeding parameters for selection. The overall mean for TC in the seventh year for scions budded on to MR was 46.4 $\mathrm{cm}$ versus $43.8 \mathrm{~cm}$ for scions on $\mathrm{AR}$; highest $\mathrm{TC}$ the seventh year was recorded for scions of RRII 105 on MR $(52.7 \mathrm{~cm})$ whereas TC for RRII 118 on AR was 51.7 $\mathrm{cm}$ in the seventh year (Table 3). RRII 118 had the largest overall stem circumference at age seven $(52.2$ $\mathrm{cm})$ but this was not significantly different than the clone with the smallest TC at the same age, RRII 208
$(38.7 \mathrm{~cm})$. The pooled average (across clones) TC at opening (after seven years) was not significantly affected by rootstock type $\left(\mathrm{F}_{1,7}=2.19, P=0.18\right)$ or rootstockscion interaction, although a scion effect was barely significant $(P<0.0442)$. The mean TC of all scions after 19 years on monoclonal root stocks $(86.8 \mathrm{~cm})$ was not significantly $(P<0.05)$ different than the mean for all scions on random root stocks $(82.6 \mathrm{~cm})$. RRII 118 had the largest TC after 19 years of growth (MR: $91.4 \mathrm{~cm}$; AR: $88.8 \mathrm{~cm})$. RRII 105 had the greatest TC at age 1 $(11.9 \mathrm{~cm},=3.7 \mathrm{~cm}$ in diameter) when budded on AR versus MR $(11.3 \mathrm{~cm})$. Branch number at the age three was greatest for clone RRII 118 budded onto MR (3.1) versus AR (2.7); Gl1 had the fewest branches (on AR) in the third year of growth. Number of branches did not significantly differ among clones irrespective of stock, the average number of branches across different clones budded on MR (2.4) compared to that of AR (2.3) was not significantly $(P<0.05)$ different. Among the seven clones evaluated, highest branching height was recorded for RRII 105 (2.5 m when budded on MR and $2.8 \mathrm{~m}$ on AR). Gl1 had lowest branching height, $2.3 \mathrm{~m}$ for trees on MR rootstocks, $2.0 \mathrm{~m}$ for trees on $\mathrm{AR}$.

Analysis of variance (Table 4) showed no significant differences among clones $(P<0.01)$ for any juvenile characters, including early height, girth, number of branches and branching height. Rootstock and interaction (clone $\mathrm{x}$ rootstock) effects also were not significant for these traits. A similar result was obtained for TC at opening and TC after 19 years, although, as described above, there were barely significant differences among clones for TC at opening $(P<0.0442)$. Rootstock and rootstock $\mathrm{x}$ scion effects were non-significant at age 19 . 
Table 3. - Juvenile characteristics and trunk circumference.

\begin{tabular}{|c|c|c|c|c|c|c|c|c|c|c|c|c|}
\hline \multirow{3}{*}{ Clones } & \multicolumn{8}{|c|}{ Juvenile characters ${ }^{2}$} & \multicolumn{4}{|c|}{ Trunk cireumference } \\
\hline & \multicolumn{2}{|c|}{$\begin{array}{l}\text { Height }^{y} \\
\text { (m) }\end{array}$} & \multicolumn{2}{|c|}{$\begin{array}{l}\text { Trunk } \\
\text { Circum- } \\
\text { ference } \\
\text { (cm) }\end{array}$} & \multicolumn{2}{|c|}{$\begin{array}{c}\text { Number } \\
\text { of branches }\end{array}$} & \multicolumn{2}{|c|}{$\begin{array}{l}\text { Branching } \\
\text { height }^{x} \\
\text { (m) }\end{array}$} & \multicolumn{2}{|c|}{$\begin{array}{c}\Lambda \mathrm{t} \\
\text { opening }^{\mathrm{x}} \\
(\mathrm{cm})\end{array}$} & \multicolumn{2}{|c|}{$\begin{array}{c}\text { After } \\
19 \text { years } \\
(\mathrm{cm})\end{array}$} \\
\hline & $\mathrm{MR}$ & $\mathrm{AR}$ & $\mathrm{MR}$ & AR & MR & $\mathrm{AR}$ & $\mathrm{MR}$ & $\mathrm{AR}$ & MR & $\mathrm{AR}$ & $\mathrm{MR}$ & $\mathrm{AR}$ \\
\hline RRII 105 & 3.9 & 4.0 & 11.3 & 11.9 & 2.5 & 2.8 & 2.5 & 2.8 & 52.7 & 51.7 & 87.4 & 89.2 \\
\hline RRII 118 & 3.6 & 3.3 & 11.3 & 11.5 & 3.1 & 2.7 & 2.6 & 2.6 & 52.2 & 51.3 & 91.4 & 88.8 \\
\hline RRII 203 & 2.9 & 3.2 & 10.6 & 10.8 & 2.9 & 2.5 & 2.4 & 2.2 & 43.2 & 44.5 & 82.4 & 76.3 \\
\hline RRII 208 & 2.5 & 2.7 & 11.1 & 11.1 & 2.1 & 2.0 & 2.3 & 2.1 & 38.7 & 37.4 & 81.0 & 79.7 \\
\hline $\mathrm{GT} 1$ & 2.6 & 2.6 & 10.9 & 10.9 & 2.2 & 2.4 & 2.3 & 2.2 & 52.1 & 40.0 & 88.5 & 84.4 \\
\hline G1 1 & 2.5 & 2.1 & 10.5 & 10.2 & 1.9 & 1.6 & 2.3 & 2.0 & 43.2 & 37.4 & 88.2 & 82.4 \\
\hline RRIM 600 & 2.5 & 3.0 & 11.0 & 10.4 & 1.8 & 2.3 & 2.1 & 2.3 & 43.0 & 44.4 & 82.4 & 88.9 \\
\hline Mean & 2.9 & 3.0 & 10.9 & 11.1 & 2.4 & 2.3 & 2.4 & 2.3 & 46.4 & 43.8 & 86.8 & 82.6 \\
\hline $\mathrm{CV}$ & 24.9 & & 7.5 & & 28.7 & & 13.9 & & 7.9 & & 6.4 & \\
\hline
\end{tabular}

${ }^{z}$ All comparisons of MR versus AR not significant at $P=0.05$, see Table 4, all tabulated data are means $(\mathrm{n}=50)$.

y $1^{\text {st }}$ year after planting, all comparisons were not significant at $P=0.05$, see Table 4 .

$\times 3^{\text {rd }}$ year after planting.

w $7^{\text {th }}$ year after planting.

Table 4. - Mean square values of analysis of variance for the effect of stock, scion and their interaction on juvenile and mature growth characters.

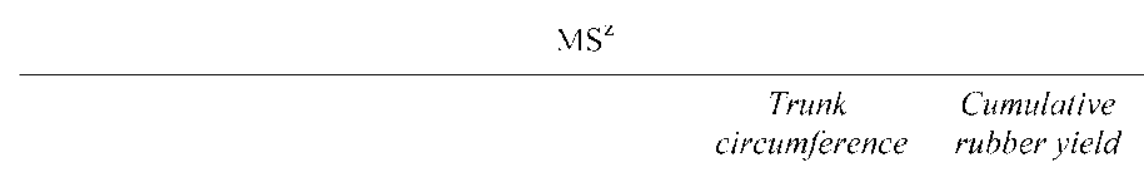

\begin{tabular}{|c|c|c|c|c|c|c|c|c|c|}
\hline $\begin{array}{l}\text { Source of } \\
\text { variation }\end{array}$ & $\mathrm{dl}^{*}$ & F Teight $t^{x, *}$ & $\begin{array}{l}\text { Trunk } \\
\text { circum- } \\
\text { ference }^{x, w}\end{array}$ & $\begin{array}{c}\text { Number } \\
\text { of } \\
\text { branches }^{x, y}\end{array}$ & $\begin{array}{l}\text { Branching } \\
\text { height. }\end{array}$ & $\begin{array}{c}\text { At } \\
\text { opening }\end{array}$ & $\begin{array}{l}\text { At } \\
\text { age } \\
19^{\mathrm{x}}\end{array}$ & $\begin{array}{c}\text { At } \\
\operatorname{agc} \\
11^{\mathrm{xu}}\end{array}$ & $\begin{array}{c}\mathrm{Al} \\
\operatorname{age} \\
19^{\mathrm{x}, \mathrm{u}}\end{array}$ \\
\hline Clone & 6,6 & 2.39 & 0.66 & 0.93 & 3.35 & $4.53 *$ & 1.08 & 0.71 & 0.77 \\
\hline Rootstock & 1,7 & 0.05 & 0.48 & 0.03 & 0.30 & 2.19 & 2.10 & 1.32 & 1.37 \\
\hline Clone $x$ & 6.7 & 0.55 & 0.16 & 0.53 & 0.85 & 1.02 & 0.30 & 0.79 & 0.72 \\
\hline rootstock & & & & & & & & & \\
\hline
\end{tabular}

${ }^{z}$ Type 3 test of fixed effects.

${ }^{\mathrm{y}} \mathrm{X}, \mathrm{Y}$ where $\mathrm{X}=\mathrm{df}$ for the numerator, $\mathrm{Y}=\mathrm{df}$ for the denominator.

x Only effects indicated with asterisk (*) significant $P<0.05$.

${ }^{\text {w }}$ Measured in $1^{\text {st }}$ year of growth.

${ }^{v}$ Measured in $3^{\text {rd }}$ year of growth.

u Cumulative yield of 11-year-old trees = first 4 years after opening; cumulative yield of 19-year-old trees $=$ first 12 years after opening. 


\section{Discussion}

Vegetative propagation through bud grafting is an accepted practice in the production of planting material in Hevea. The present investigation confirms that the difference between monoclonally derived seedling rootstocks and the randomly selected seedling rootstocks used in the study were not significantly different in their effect on growth and dry rubber yield. Difference in performance largely depended on the genotype of the scion. The study was unique in terms of its longevity and emphasis on the most important economic traits, i.e., dry rubber yield and growth. Previous studies of Hevea rootstock-scion interactions have focused on isoenzymes (KRISHNAKUMAR et al., 1992), identification and analysis of proteins related to rootstock-scion interactions (YUAN et al., 2011), genetic relationship of polyclonal seedlings raised from cultivated clones (THOMAS et al., 2004), intraclonal variability (ALIKA, 1980; CHANDRASEKHAR et al., 1997), and growth and yield of scion (DiJKMAN, 1951; BUTTERY, 1961; YAHAMPATH, 1968; YEANG et al., 1995; SAGY and OMOKHAFE, 1996). None of these studies considered the long term effect of MR and AR except NG et al. (1981), who suggested use of poly clonal seeds rather than monoclonal stocks for enhanced yield of the scion. The results of the present study are not completely in agreement with $\mathrm{NG}$ et al. (1981) and GonCALVES et al. (1994) since we found that in general the tested rootstocks imparted no influence on the growth and yield of different scions. Similar results reported in tea wherein the taste traits showed significant differences in quality score between scions, but no differences between rootstocks, nor any stock $\times$ scion interaction (TUwEI et al., 2008). Studies by TANDONNET et al., (2010) in young grafted grapevines, also demonstrated the major effect of the scion genotype on most of the parameters of development, especially in the root.

Results of the present study indicated that healthy assorted root stocks and seedling stock from (presumably self-pollinated) seeds from monoclonal plantations do not result in differences in the growth and yield of clonal scions. Future conditions such as the outbreak of wide spread disease may warrant root stock selection and even breeding for elite stocks.

\section{Acknowledgment}

We thank Dr. JAMES JACOB, Director of Research and former Directors of Rubber Research Institute of India for their continuous encouragements and support for this long term study. Cooperation extended by the supporting staff at Central Experiment Station at Chethackal during the whole experimental period is gratefully acknowledged. The financial support for this study provided by the Rubber Board of India is thankfully acknowledged.

\section{References}

ALIKA, J. E. (1980): Estimates of repeatability and coefficient of variation in rubber (Hevea brasiliensis Muell. Arg.). Silvae Genetica 29: 5-6.
Annamma, Y., J. G. Marattukalam, D. Premakumari, C. K. Saraswathiamma, J. Licy and A. O. N. Panikar (1990): Promising rubber planting materials with special reference to Indian clones. Proceedings of Planters' Conference, Rubber Research Institute of India, Kottayam, India, 1991, 62-70.

BUTTERY, B. R. (1961): Investigation into the relationship between stock and scion in budded trees of Hevea brasiliensis. Journal of Rubber Research Institute of Malaysia 17: 46-76.

Cardinal, A. B. B., P. S. Goncalves and A. L. M. Martins (2007): Stock scion interactions on growth and rubber yield of Hevea brasiliensis. Scientia Agricola 64(3): 235-240.

Castle, W. S. and C. O. Youtsey (1998): Root system characteristics of citrus nursery trees. Proceedings of Florida State Horticulture Society 90, 39-44.

Chandrasekhar, T. R., K. K. Mydin, J. Alice, Y. A. VargHESE and C. K. SARASWATHYAMMA (1997): Intraclonal variability for yield in rubber (Hevea brasiliensis). Indian Journal of Natural Rubber Research 10(1\&2): 43-49.

DiJKMAN, M. J. (1951): Hevea: thirty years of research in the Far East. University of Miami Press, Florida, USA. $329 \mathrm{pp}$.

Goncalves, P. S., A. L. M. Martins, E. P. Gorgulho, N. BorTOLETTO and G. BERMOND (1994): Influence of six root stocks on growth of six scion clones of rubber: a preliminary report. Pesquisa Agropecuária Brasileira 29(4): 553-560.

Jensen, P. J., J. Rytter, E. A. Detwiler, J.W. Travis and T.W. McNellis (2003): Root stock effects on gene expression pattern in apple tree scions. Plant Molecular Biology 493: 493-511.

Krishnakumar, R., M. P. Ashokan and M. R. SethuraJ (1992): Polymorphic isoenzyme expression caused by stock-scion interaction in Hevea brasiliensis clone RRII 105. Indian Journal of Natural Rubber Research 5(1\&2): 161-171.

Licy, J., C. K. Saraswathyamma, D. Premakumari, T. Meenakumari, J. R. Meenattoor and M. A. Nazeer (2003): Genetic parameters and heterosis in rubber (Hevea brasiliensis) Muell. Arg. V. Hybrid vigour for yield and yield components among the RRII 400 series clones in small scale evaluation. Indian Journal of Natural Rubber Research 16(1\&2): 75-80.

NAIR, V. K. B. and P. J. GEORGE (1969): The Indian clones: RRII 100 series. Rubber Board Bulletin 10: 115-140.

NaIR, V. K. B., P. J. George and C. K. Saraswathyamma (1975): Breeding improved Hevea clones in India. Proceeding of International Rubber Conference, Kula Lumpur, Malaysia. 2: 45-54.

Ng, A. P., C. Y. Ho, M. O. Sultan, C. E. Ooi, H. L. Lew and P. K. Yoon (1981): Influence of six root stocks on growth and yield of six scion clones of Hevea brasiliensis. Proceeding of Planters' Conference, Rubber Research Institute of Malaysia, Kuala Lumpur, Malaysia, 1981, 134-151.

Premakumari, D., R. B. NAIR, T. A. Soman, A. John and M. A. NAZEER (2002): Genetic influence for intraclonal variations and associations of juvenile yield and girth in thirteen Hevea clones grown Kanyakumari region of South India. Indian Journal of Natural Rubber Research 15(1): 28-32.

Priyadarshan, P. M. and A. Clement-Demange (2004): Breeding Hevea Rubber: Formal and molecular genetics. Advances in Genetics 52: 51-115. 
Punnoose, K. I., R. Kothandaraman, V. PhiliP and M. D. JESSY (2000): Field upkeep and intercropping, pp. 150-169. In: Natural Rubber: Agromanagement and crop processing, edited by GEORGE, P. J. and C. K. JACOB, Rubber Research Institute of India, Kottayam, India.

RRIM (1970 a): Review of modern Hevea clones: 1. Clone RRIM 600. Planters' Bulletin 107: 49-64.

RRIM (1970b): Review of modern Hevea clones: 2. Clone GT 1. Planters' Bulletin 109: 113-134.

SAGY, G. A. and K. G. OMokhafe (1996): Evaluation of rootstock and scion compatibility in Hevea brasiliensis (3). Paper presented at the IRRDB seminar, 5-8 November 1996, Sri Lanka. 13p.

SAlazar, D. M., M. Miro and S. Garcia (1991): Root stocks for dry region apricot tree faced with Capnodis tenebrionis L. Acta Horticulture 293: 401-404.

Saraswathyamma, C. K., P. J. George, A. O. N. Panikkar, N. M. Claramma, J. G. Marattukalam and V. K. B. Nair (1990): Performance of RRII selections from 1956 breeding programme in the large scale trial. National Symposium on New trends in Crop Improvement of Perennial Species, Kottayam, India, August 30, 1990, 134 pp.

SENANAYAKe, Y. D. A. (1975): Yield variability in clonal rubber (Hevea brasiliensis, Muell. Arg.). Journal of Plantation Crops 3(2): 73-76.

Senanayake, Y. D. A., N. E. M. Jayasekara and P. SAmaRANAYAKE (1975): Growth of nursery root stock seedlings of Hevea brasiliensis Muell. Arg. Cv. Tjir 1. Part II. Quarterly Journal of Rubber Research Institute of Sri Lanka 52: 29-37.

Sharma, V. K. and D. P. UniYal (2003): Short Note: Delayed Graft Incompatability in Heteroplastic Interspecific Graft Between Tectona grandis L. f. and Tectona hamiltoniana Wall after three decades. Silvae Genetica 52(1): 24-25.

SharP, C. C. T. (1940): Programme of breeding investigations with Hevea brasiliensis. Journal of Rubber Research Institute of Malaysia 10: 34-66.

Sobhana, P., G. Jayasree, J. James and M. R. SethuraJ (2001): Physiological and biochemical aspects of stockscion interaction in Hevea brasiliensis. Indian Journal of Natural Rubber Research 14(2): 131-136.
TAndonnet, J.-P., S. Cookson, P. VIVIN and N. Ollat (2010): Scion genotype controls biomass allocation and root development in grafted grapevine. Australian Journal of Grape and Wine Research 16: 290-300.

Thomas, M., M. B. M. Sathik, C. P. Reghu and J. JacoB (2004): RAPD analysis of genetic distance among Hevea clones differing in vigour. Journal of Plantation Crops 32 (Suppl.): 152-155.

Tombesi, S., R. S. Johnson, K. R. DAY and T. M. DEJong (2010): Interactions between rootstock, inter-stem and scion xylem vessel characteristics of peach trees growing on rootstocks with contrasting size-controlling characteristics. AoB Plants 2010: 1-9. [doi:10.1093/aobpla/ plq013http://aobplants.oxfordjournals.org/]

Tuwei, G., F. K. K. KaPtich, M. C. Langat, K. C. Chomboi and R. H. V. CoRLeY (2008): Effects of Grafting on Tea 1. Growth, yield and quality. Experimental Agriculture 44: 521-535.

WhitBY, G. S. (1919): Variation in Hevea brasiliensis. Annals of Botany 31, 313-321.

YAHAMPATH, C. (1968): Growth rate of PB 86 on different Hevea root stock. Quarterly Journal of Rubber Research Institute of Cylon 44: 27.

Yeang, H. Y., R. Wickneswari, E. Sundarasan, S. K. LeONG, H. H. AsRI, D. M. NAPI, A. S. M. ZAMrI and M. N. A. GHANI (1995): Isoenzymes in Hevea crop improvement. IRRDB symposium on physiological and molecular aspects of the breeding of Hevea brasiliensis, England, 1995, 52-57.

YIN, J. P. T. (2004): Root stock effect on Cocoa in Sabah, Malaysia. Experimental Agriculture 40: 445-452.

YuAN, K., X. Ding, L. YANG, Z. WANG, W. Lin and J-H. CAO (2011): Proteome analysis of interaction between rootstocks and scions in Hevea brasiliensis. African Journal of Biotechnology 10(66): 14816-14825.

ZHU, L., M. WELANDER and O. HELLGREN (1999): Growth rates, biomass production of micropropagted apple plants of M26 and Gravenstein on their own roots and in different micrografted combinations under non-limiting and limiting nutrient conditions. Journal of Experimental Botany 50(336): 1189-1198. 